\title{
Educational standards for developing an entry-level occupational therapy program: an overview
}

\begin{abstract}
The objective of this article is to provide an overview of the minimum educational standards required for developing an entry-level educational program in occupational therapy and to encourage continual quality assurance for developments required to advance the profession in an inter-professional and global context. Impacting the profession through the establishment of international standards is the key to provide a global unifying approach to the curriculum ongoing development of quality entrylevel programs in occupational therapy. These standards ensure that the design and delivery of occupational therapy educational programs are internationally consistent and identify the essential knowledge, skills, and attitudes that encourage a more competent practice of occupational therapy.
\end{abstract}

Volume I Issue 5 - 2018

\author{
Hassan Izzeddin Sarsak \\ Department of Occupational Therapy, Batterjee Medical \\ College, KSA
}

\begin{abstract}
Correspondence: Hassan Izzeddin Sarsak (PhD, OT), Department of Occupational Therapy, Batterjee Medical College, Jeddah, KSA, Email hassan.sarsac@bmc.edu.sa,
\end{abstract} sarsachassan@gmail.com

Received: October 22, 2018 | Published: October 29, 2018

Keywords: educational standards, entry-level, occupational therapy, curriculum, world federation of occupational therapy

\section{Introduction}

Occupational therapy (OT) is recognized by the World Health Organization $^{1}$ as a health profession which is represented by the World Federation of Occupational Therapy. ${ }^{2}$ The WFOT was established in 1952 and is the official international organization that supports and promotes occupational therapy profession. As members of health teams, occupational therapists work with other health professionals and share the occupational therapy's unique body of knowledge on occupation. Occupations are those purposeful and meaningful functional activities of everyday living. The occupational therapists knowledge and practice embrace a client-centered, holistic, and dynamic perspective of the person, the occupation, and the environment. ${ }^{3}$ This integrated practice approach makes occupational therapy's contribution to rehabilitation, recovery and health so effective. ${ }^{4}$

Curriculum design and development is one of the first stages in developing a new educational program. In 1958, the WFOT established a program for the Education of Occupational Therapists. The education program area of the WFOT is charged with evaluating a qualifying educational program from countries applying for membership of the WFOT. Since then, the minimum standards have shaped the global curriculum development of occupational therapy entry-level programs (Bachelor's Degree or Equivalent Credential). The WFOT provided the Minimum Standards for the Education of Occupational Therapists (MSEOT) and has been thoroughly reviewing and updating them. These international standards provide a global unifying approach to the curriculum design and development of quality entry-level programs in occupational therapy. ${ }^{6}$ They ensure that the design and delivery of occupational therapy educational programs are internationally consistent and help identify the essential knowledge, skills, and attitudes that encourage a more competent practice of occupational therapy. This practice helps occupational therapist to be able to work in a diversity of multiple settings and cultures and educate the next generation of therapists to manage and adapt services from local to global contexts. ${ }^{7}$ While these standards shed light on the broader perspective of international practice, they also encourage a strong emphasis on local contexts and cultural differences. MSEOT state that the preparation of entry-level occupational therapists to meet the challenges of the $21^{\text {st }}$ century requires continuous modifications to learning experiences as well as new strategies to develop the knowledge, skills, and attitudes that are needed to achieve the necessary entry-level competencies. In addition, occupational therapy's entry-level education must be anticipatory not just responsive to growing health challenges. Furthermore, it should prepare capable students for the complexity of emerging academic and evidence-based practice. ${ }^{4}$ Additionally, the MSEOT don't only look at technical, clinical, and professional skills but also help enhance leadership, adaptability as well as soft skills (i.e., communication skills, political awareness, advocacy, etc. $)^{8}$ that are essential within the $21^{\text {st }}$ century for advancement of all knowledge based occupations. ${ }^{9}$

The individuals who design an occupational therapy curriculum and those who educate occupational therapy students need to be well-informed of the MSEOT. Therefore, the purpose of this article is to provide an overview of the minimum standards required for developing an entry-level educational program in the field of occupational therapy and to encourage continual quality assurance for developments required to advance the profession in an interprofessional and global context.

\section{Methods}

The most recent version of the MSEOT revised in 2016 was reviewed. The minimum standards required for developing an entrylevel occupational therapy educational program were highlighted. Our review focused on knowledge, skills, and attitudes that encourage a more competent practice of occupational therapy and provided an overview of the essential components of the entry-level occupational therapy educational program.

\section{Summary of results ${ }^{4}$}

\section{Philosophy and purpose of the program}

Occupational therapy educational programs $\mathrm{s}^{10}$ are guided by a unique philosophical understanding of local and international perspectives of occupation. The programs philosophical understanding of occupation 
may include but not limited to: the nature and meaning of occupation, individual's participation in occupation, and cultural understandings of occupational performance and outcomes. When developing an educational program, the curriculum designers and educators need to understand the social and educational background of students entering the program, such as the educational methodologies that the students are familiar with, the student's preexisting knowledge, and the demands of external roles of adult students (i.e., worker, spouse, and parent). The purpose of the educational program refers to the kind of work the students are primarily being prepared to do and the range of settings within which they are expected to be able to work. Both philosophy and purpose are central to the educational program and guide all aspects of the program design, curriculum content, professional development, program delivery and outcomes.

\section{Essential knowledge, skills, and attitudes for competent practice}

All graduated occupational therapists are expected to have knowledge, skill, and attitudes in the following areas:
a. The person-occupation-environment relationships
b. Relationship of occupation to health and well-being
c. Therapeutic and professional relationships
d. The occupational therapy process
e. Professional reasoning and behavior
f. The local and global contexts of professional practice

\section{Factors of the local context}

In order to produce graduates with these knowledge, skill, and attitudes, the following five factors of the local context that influence what needs to be taught in an occupational therapy educational program and how it is taught need to be taken into consideration:

i. The students ability to complete the program successfully

ii. Local health and social needs

iii. Local health, societal, disability educational and legal systems

iv. Local beliefs, values, and meaning of occupations in the local context

v. Local occupational therapy history

\section{Components of the educational program}

All occupational therapy educational programs should include five components, all of which should be developed to be consistent with the program philosophy and purpose.

These components are:
A. Curriculum content and sequence
B. Educational methods
C. Practice placements (fieldwork)
D. Expertise of educators
E. Educational resources and facilities

Figure 1 summarizes and illustrates the relationship between the program philosophy and purpose, the essential knowledge skills and attitudes for competent practice, the factors of the local context, and the components of the occupational therapy educational program. ${ }^{4}$

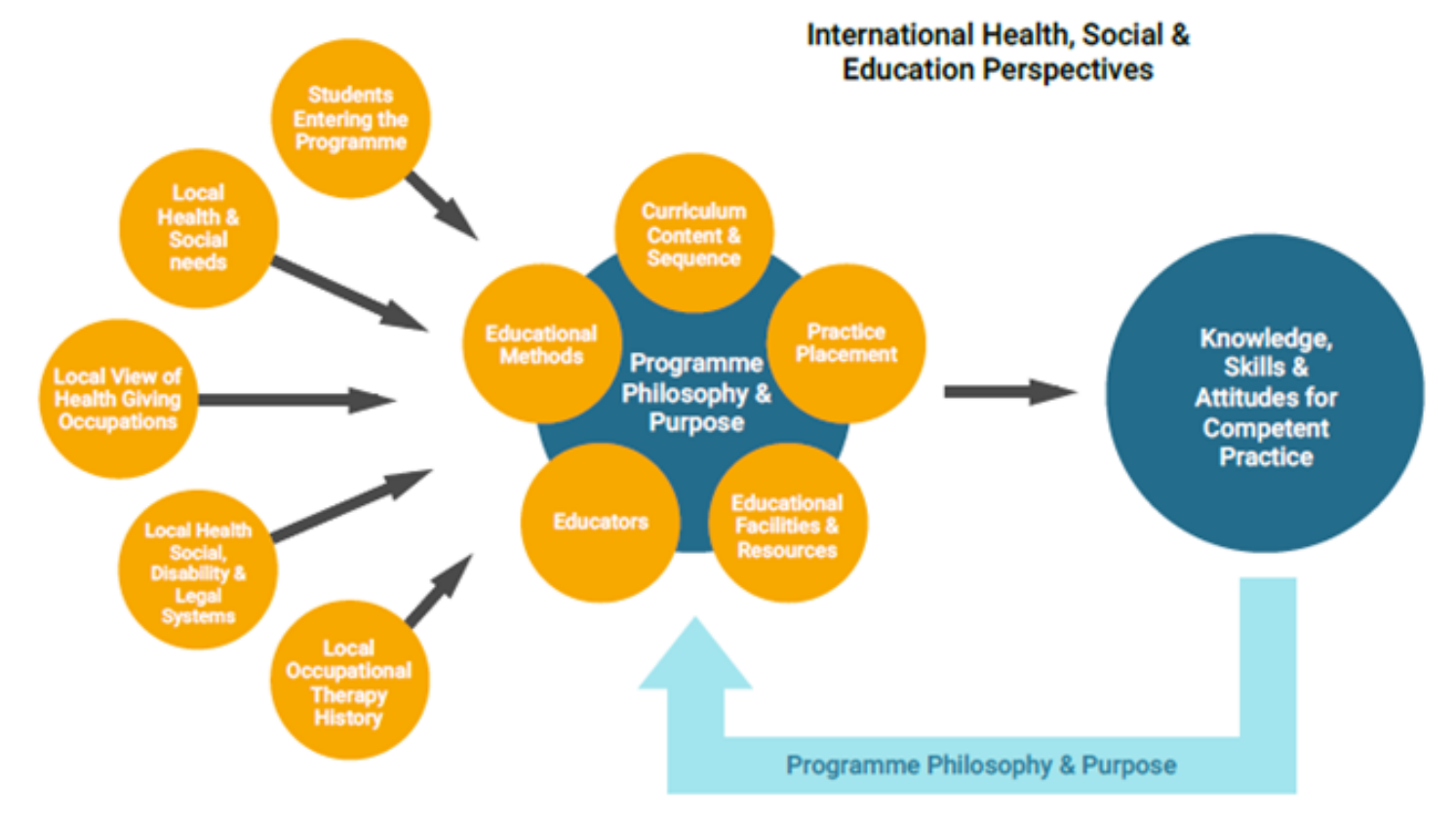

Figure I The Relationship between Program Philosophy and Purpose, Essential Knowledge Skills and Attitudes for Competent Practice, Factors of Local Context, and Components of an Occupational Therapy Educational Program (adapted from WFOT MSEOT, Revised, 2016).

\section{Discussion}

The WFOT MSEOT are intended to set a minimum standard and encourage a continual quality assurance for developments required to advance the profession in an inter-professional and global context. ${ }^{5}$
The MSEOT to prepare entry-level occupational therapists are organized in the 2016 revised version under six headings. Under each heading, the minimum standards address five issues. Table 1 summarizes the WFOT MSEOT. ${ }^{3}$ 
Table I A summary of the WFOT MSEOT ${ }^{4}$

\begin{tabular}{|c|c|c|c|c|c|}
\hline Standard & Congruence & Depth and breadth & Local context & $\begin{array}{l}\text { International } \\
\text { perspective }\end{array}$ & Quality assurance \\
\hline $\begin{array}{l}\text { Philosophy } \\
\text { and } \\
\text { purpose }\end{array}$ & $\begin{array}{l}\text { The elements of } \\
\text { the philosophy and } \\
\text { purpose statements } \\
\text { fit together well, } \\
\text { and provide a } \\
\text { comprehensive basis } \\
\text { for the program. }{ }^{10}\end{array}$ & $\begin{array}{l}\text {-The philosophy addresses an } \\
\text { occupational view of humans, the } \\
\text { occupational challenges humans } \\
\text { face, and how to enable occupation. } \\
\text {-The purpose includes individual, } \\
\text { community/group and population } \\
\text { approaches to health and well-being. }\end{array}$ & $\begin{array}{l}\text { The philosophy and } \\
\text { purpose of the program } \\
\text { are aligned with current } \\
\text { or predicted health } \\
\text { and well-being needs, } \\
\text { occupations, and systems } \\
\text { and priorities of the } \\
\text { nation or geographical } \\
\text { region in which the } \\
\text { program is located. }\end{array}$ & $\begin{array}{l}\text { The philosophy } \\
\text { and purpose of } \\
\text { the program } \\
\text { reflect concepts } \\
\text { of occupation } \\
\text { and occupational } \\
\text { therapy shared by } \\
\text { the international } \\
\text { community of } \\
\text { occupational } \\
\text { therapists. }\end{array}$ & $\begin{array}{l}\text { The philosophy and } \\
\text { purpose statements } \\
\text { are reviewed in an } \\
\text { on-going manner, and } \\
\text { revised in response } \\
\text { to local changes } \\
\text { and development } \\
\text { of international } \\
\text { knowledge. }\end{array}$ \\
\hline $\begin{array}{l}\text { Curriculum } \\
\text { content } \\
\text { and } \\
\text { sequence }\end{array}$ & $\begin{array}{l}\text { The curriculum } \\
\text { content and the } \\
\text { sequence of content } \\
\text { fit well with the } \\
\text { program philosophy } \\
\text { and purpose. }\end{array}$ & $\begin{array}{l}\text {-The curriculum is designed } \\
\text { and developed by occupational } \\
\text { therapists. } \\
\text {-A minimum of } 60 \% \text { of a program } \\
\text { is focused on occupation and } \\
\text { occupational therapy } \\
-10-30 \% \text { of the program is focused } \\
\text { on knowledge of body structures } \\
\text { and functions, biomedicine, } \\
\text { psychological and sociological } \\
\text { concepts } \\
-10-30 \% \text { of the program is focused }\end{array}$ & $\begin{array}{l}\text { The curriculum content } \\
\text { is congruent with the } \\
\text { local social, cultural } \\
\text { and institutional } \\
\text { environments. }\end{array}$ & $\begin{array}{l}\text { The curriculum } \\
\text { content is based } \\
\text { on contemporary } \\
\text { international theories, } \\
\text { research findings, } \\
\text { occupational therapy } \\
\text { practice, international } \\
\text { documents (i.e., } \\
\text { WHO ICF), \& links } \\
\text { with the international } \\
\text { occupational therapy } \\
\text { community }\end{array}$ & $\begin{array}{l}\text { The curriculum is } \\
\text { reviewed on an on- } \\
\text { going basis and revised } \\
\text { at least every } 5 \text { years } \\
\text { (for } 2 \text { or } 3 \text { year } \\
\text { programs) or } 7 \text { years } \\
\text { (for } 4 \text { year programs) } \\
\text { including (i.e., peer and } \\
\text { self-review, student } \\
\text { feedback, monitoring } \\
\text { processes, advisory } \\
\text { boards, external } \\
\text { examiners) }\end{array}$ \\
\hline
\end{tabular}

Educational The educational methods methods selected are consistent with the views of people and occupation that are illustrated within the philosophy and purpose of the program. on knowledge of the human and social environments

\section{-Occupational therapy} undergraduate programs in higher education are a minimum of 3 years or 90 weeks.

The range of educational methods used (i.e., case studies, skills training, small scale projects, reflective exercises, literature review, experiential learning, problem-based learning, inter-professional learning) supports the development of graduate knowledge, cognitive and practice skills, and fosters lifelong learning.'

\section{-Students practice a range of practice education (age groups, diagnoses, and contexts)}

\section{Education}

Practice education experiences are consistent with the philosophy and purpose of the program.
-Each student will complete sufficient hours of practice placements

-A minimum of $\mathrm{I}, 000$ hours is expected.

-Supervision will progress from close, on-site supervision to independent practice as student progresses.

-Supervision models are not limited to a I:I student-therapist ratio.
-Local experts are utilized as well as people with occupational dysfunction.

-Local traditions of teaching and learning are valued and incorporated.
Educational practices are informed by international educational theories and research, and utilize information and communication technology.
Processes for continual improvement that use multiple information sources (i.e., peer review, student \& graduate feedback, examination boards, educational experts)
-Practice education experiences are informed by international expectations of professional service provision.

-Practice is guided by theory and research findings, and service is provided to all people without prejudice.
Evaluation of student performance on practice placements is consistent with the philosophy and purpose of the program, clear and explicit, and appropriate to the level of the student.
-Students and pract educators are adequately prepared and supported to fulfill their roles and responsibilities.

.


Table Continued....

\begin{tabular}{lll}
\hline Standard & Congruence & Depth and breadth \\
\hline $\begin{array}{l}\text { Educational } \\
\text { facilities } \\
\text { and }\end{array}$ & $\begin{array}{l}\text { The educational } \\
\text { resources fit well } \\
\text { with the philosophy } \\
\text { and purpose of the } \\
\text { program. }\end{array}$ & $\begin{array}{l}\text {-The size of the student intake is } \\
\text { in proportion with the number of } \\
\text { educators. }\end{array}$ \\
& $\begin{array}{l}\text {-There are sufficient resources, } \\
\text { including library resources, internet } \\
\text { access, teaching materials, specialist } \\
\text { equipment and funding to support } \\
\text { effective teaching and learning. }\end{array}$
\end{tabular}

-There is adequate and accessible teaching space, offices for educators and support staff, venues for specialist learning activities, and storage space.

$\begin{array}{ll}\text { Educators } & \text { The mix of } \\ \text { professional } \\ \text { backgrounds, } \\ \text { qualifications and } \\ \text { experience of the } \\ \text { educators enables } \\ \text { delivery of an } \\ \text { educational program } \\ \text { that fits its stated } \\ \text { philosophy and } \\ \text { purpose. }\end{array}$

-Qualifications and experience of the educators support the curriculum content and educational methods.

-Educators demonstrate excellence in teaching " and have qualification that is higher than the qualification received by graduates of the program. ${ }^{12}$

-There is a staff policy that addresses a balance of teaching, research and administrative functions.

Local context
Examples of equipment
that would be used
with the recipients of
occupational therapy and
materials for therapeutic
occupations fit the local
technology, economy,
values and geography.

The educators have, or can access, knowledge of local contexts of practice (i.e., understanding local occupations, social structures, cultural beliefs and practices, health needs, and occupational opportunities)

\begin{tabular}{|c|c|}
\hline $\begin{array}{l}\text { International } \\
\text { perspective }\end{array}$ & Quality assurance \\
\hline $\begin{array}{l}\text {-Library resources } \\
\text { are up-to-date, and } \\
\text { supported by internet } \\
\text { access. } \\
\text {-The program has } \\
\text { student and staff } \\
\text { recruitment and } \\
\text { selection policies and } \\
\text { procedures to ensure } \\
\text { equal opportunities } \\
\text { for all. } \\
\text {-Learning resources } \\
\text { need to include } \\
\text { access to international } \\
\text { databases and journals. }\end{array}$ & $\begin{array}{l}\text { Plans for continual } \\
\text { improvement of } \\
\text { facilities and resources } \\
\text { are in place and } \\
\text { consistent with } \\
\text { planned curriculum } \\
\text { development. }\end{array}$ \\
\hline $\begin{array}{l}\text { The educators } \\
\text { access international } \\
\text { occupational } \\
\text { therapy, health, } \\
\text { disability, societal } \\
\text { and educational } \\
\text { thinking and practice } \\
\text { (i.e., international } \\
\text { professional literature, } \\
\text { visiting educators, } \\
\text { and interational } \\
\text { conferences, } \\
\text { networking). }\end{array}$ & $\begin{array}{l}\text { The educators } \\
\text { update continually } \\
\text { the knowledge, skills } \\
\text { and attitudes relevant } \\
\text { to their teaching } \\
\text { (i.e., gaining further } \\
\text { formal qualifications, } \\
\text { international } \\
\text { collaboration } \\
\text { with experts and } \\
\text { organizations, engaging } \\
\text { in research, student } \\
\text { feedback, critical } \\
\text { appraisal of teaching } \\
\text { practice). }\end{array}$ \\
\hline
\end{tabular}

2. Krug E, Cieza A. Strengthening health systems to provide rehabilitation services. Bulletin of the World Health Organization, 2017;95:167.

3. World Federation of Occupational Therapists (WFOT). Position Statement: Environmental Sustainability: Sustainable Practice within Occupational Therapy. 2012.

4. World Federation of Occupational Therapists (WFOT). Minimum Standards for the Education of Occupational Therapist. 2016.

5. World Federation of Occupational Therapists (WFOT). Developing an occupational therapy profession in non-Member Countries. 2008.

6. World Federation of Occupational Therapists (WFOT). Educational Programmes Quality AssurancePackage(EQAP). 2012.

7. World Federation of Occupational Therapists (WFOT). Position Statement: Diversity and Culture. 2010.

8. Gow K, Mc Donald P Attributes required of graduates for the future workplace. J Vocation Educ Train. 2000;52(3):373-396.

9. Fortune T, Ryan S, Adamson L. Transition to practice in super complex environments: are occupational therapy graduates adequately prepared? Aust Occup Ther J. 2013;60(3):217-220.

10. World Federation of Occupational Therapists (WFOT). Position Statement: Inclusive Occupational Therapy Education. 2008.

11. World Health Organization (WHO). World Report on Disability. 2011.

12. World Federation of Occupational Therapists (WFOT). Position Statement: Academic Credentials for OT Educators. 2008.

\section{Conflict of interest}

Author declares that there is no conflict of interest.

\section{References}

1. World Health Organization (WHO). Transformative scale up of health professional education. Geneva: WHO; 2011 